\title{
Impact of invasive alien plant, Xanthium strumarium, on species diversity and composition of invaded plant communities in Borena zone, Ethiopia
}

\begin{abstract}
Biological invasion is considered as the second greatest global threat to biodiversity. An IAPS, Xanthium strumarium, is widely spread in the agricultural land, roadside, near stagnant water and disturbed land of Borena Zone, Oromia Region. However, its impact on diversity and floristic composition of the invaded plant communities has not been determined. Therefore, the objective of this study was to determine the impact of Xanthium strumarium, on the species diversity and composition of invaded plant communities in Borena Zone. Accordingly, to examine its effects of invasions on the species diversity and composition of invaded communities, ninety six $1 \mathrm{~m} 2$ quadrats were sampled (48 quadrats for invaded and 48 for non-invaded or control). There were 70 species found in the non-invaded areas as compared to 31 in the invaded areas. The number of species decreased by $55.71 \%$ in Xanthium strumarium invaded area as compared to control. The mean evenness value of the entire invaded sampled study sites was 0.27 indicated that $27 \%$ of the plant communities had uniform distribution while the mean evenness value of the controls samples was 0.74 indicated that $74 \%$ of the plant communities had uniform distribution. Thus, the heterogeneity of the invaded study sites was reduced by $47 \%$. The number of plant families was 24 in the control areas in contrast to only 15 in Xanthium strumarium invaded areas. The number of family decreased by $37.5 \%$ in invaded area as compared to control. Xanthium strumarium categorized as one of the dominant invasive alien plant species in the study area that reduced species diversity and composition of various plant species in invaded communities. Therefore, there is a need of better planning to control and eradicate the spread of Xanthium strumarium by establishing communication links between Regional, Zonal and districts Agricultural Office.
\end{abstract}

Keywords: Xanthium strumarium, invaded, non-invaded areas, diversity and composition
Volume I Issue I - 2017

\author{
Amare Seifu, Nigussie Seboka, Manaye \\ Misganaw, Tesfaye Bekele, Edget Merawi, \\ Ashenafi Ayenew, Girum Faris \\ Genetic Resources Access and Benefit Sharing Directorate, \\ Ethiopian Biodiversity Institute, Ethiopia
}

Correspondence: Amare Seifu, Genetic Resources Access and Benefit Sharing Directorate, Ethiopian Biodiversity Institute, Addis Ababa, Ethiopia, Tel +251916595709,

Email ameseifu2।@gmail.com

Received: May 26, 2017 | Published: June 30, 2017
Abbreviations: IAS, invasive alien species; CBD, convention on biological diversity; SNNPR, south nation nationality people regional state; SPSS, statistical package for social sciences; IAPS, invasive alien plant species

\section{Introduction}

Invasive Alien Species' (IAS) refers to a species, subspecies or lower taxon, introduced outside its natural past or present distributions which are widely distributed in all kinds of ecosystems throughout the world including all categories of living Organisms. IAS has been identified as the second cause of species extinction at the world level affecting the biological diversity. The extraordinary increase in the movement of wild species has accelerated the rate of introduction of new alien species everywhere, with deleterious consequences on native biological diversity. As in many other countries in the tropics hundreds of alien species have been introduced to Ethiopia, intentionally and unintentionally. ${ }^{1,2}$

IAS are of a great concern in Ethiopia, posing particular problems on biodiversity of the country, agricultural lands, range lands, national parks, water ways, lakes, rivers, power dams, roadsides and urban green spaces with great economic and ecological consequences. Among these are parthenium weed (Parthenium hysterophorus), prosopis (Prosopis juliflora), water hyacinth (Eichhornia crassipes), cactus (Euphorbia stricta), Mimosa diplotricha, Xantium strumarium and lantana weed (Lantana camara). ${ }^{3,4}$ Xanthium strumarium (English common name cocklebur, Banda in Oromiffa, Diha nikel in Amharic) is a common monoecious annual herbaceous plant species belonging to Asteraceae family. ${ }^{5}$ More than sixteen Xthanthium species have been identified and the most common are Xanthium strumarium and Xanthium spinosum. It is suspected to be the former originated from Central and North America although it was first described from Europe and the later suspected to be originated from South America. ${ }^{6,5}$ There is wide variation, both within and between Xanthium populations in: fruit size, pubescence, the number and length of spines and the degree to which the beaks and spines are hooked. ${ }^{7}$ All the Xanthium taxa are tetra-ploid having a chromosome number of $2 n=36$. The related species Xanthium spinosum is more homogeneous throughout its range than Xanthium strumarium and there is a possibility of forming hybrid between the two species. ${ }^{5}$

Xanthium strumarium is one of the invasive alien species those posing negative impacts on country's biodiversity. Xanthium strumarium has been listed as a noxious weed (prohibited plants that must be controlled) and it is a major weed of row crops such as soybeans, cotton, maize and groundnuts in many parts of the world. In 1995, it was ranked as the fourth, fifth, sixth and seventh most troublesome weed in soyabean, cotton, maize and groundnut, 
respectively. ${ }^{8}$ These rankings were based on distribution, abundance and difficulty of control. It can also invade pastures and grazing lands causing reductions in forage production. It is toxic to most domestic animals and possesses characteristics that are harmful to humans, animals and the environment. ${ }^{9}$

Xanthium strumarium also has a negative impact on livestock production. The burs lodge in animal hair and sheep wool, are difficult to remove when the wool is processed after shearing. Contaminated wool requires special treatment and may have a price penalty of $25 \%$ or more. The prickly burs can cause considerable discomfort to animals by clinging to hair on the legs and matting the tails and manes of horses. Xanthium strumarium also has an economic impact in pastures, where cattle, sheep and pigs may be poisoned by eating young plants. The cotyledons contain a toxic compound, carboxyatractyloside, which is absent in older plants. Symptoms include vomiting, muscular spasms, liver degeneration and occasionally death. Xanthium strumarium produces large amounts of highly antigenic pollen and the glandular hairs on the leaves and stem secrete a substance which causes contact dermititis in allergic individuals. ${ }^{7}$

Currently, Xanthium strumarium has been identified as one of the top 20 invasive plant species which are distributed in a widespread range across Ethiopia. ${ }^{10}$ In Ethiopia, it has showed that a high distribution status, but little is known about its impact on species richness, evenness diversity and composition of native plant species on invaded community. Xanthium strumarium is dominated on rangelands of districts in Borena zone such as: Teltele, Yabello, Dire, Miyo, Moyale, Arero and Liben districts. The study by Berhanu Lemma et al. ${ }^{11}$ also showed its wide distribution in Ethiopia particularly in rift valley regions and Borena and Guji zones of Oromia region. Similarly, another study by Mulugeta ${ }^{12}$ in Amhara region indicated relatively high abundance of Xanthium strumarium compared to Parthenium hysterophorus North Wolo.

The Ethiopian ecosystems that highly affected by Xanthium strumarium include: cultivated landmass, roadside, grazing areas, non-cultivated landmass, rural villages and urban area. ${ }^{11}$ In Ethiopia the impact of invasive plants, on the species richness, evenness, diversity and composition of invaded communities is not well studied. The impact of invasive weeds on environment, article $8(\mathrm{~h})$ of the Convention on Biological Diversity (CBD) signed by 161 countries at the Earth Summit in 1992; urges the parties to "prevent the introduction of, control, or eradicate those alien species which threaten ecosystem, habitat or species" and Ethiopia being a member of (CBD) has to play its role judiciously. Therefore, this research aims at assessing the impacts of invasive plant, Xanthium strumarium, on the species diversity and composition of invaded communities in selected district of Borena Zone, Oromia Regional State, Ethiopia. The specific objectives of the study were to compare the diversity, evenness and species richness and to determine variation in composition of plants in invaded and non-invaded plots with similar site conditions. This study helps to recommend different management options. Beside, by identifying the adverse effects of Xanthium strumarium on human, animal, crop and biodiversity, different approaches including both preventive and controlling measures will be followed. Moreover, the outcome of the study also used as a reference for other similar studies conducted in similar agro ecological situation of the country.

\section{Materials and methods}

\section{Description of the study area}

Astronomically, Borena zone is located $3^{\circ} 26^{\prime}$ to $6^{\circ} 32^{\prime} \mathrm{N}$ latitude and $36^{\circ} 43^{\prime}$ to $40^{\circ} 46^{\prime} \mathrm{E}$ longitudes. Borena zone shares common boundaries with Guji zone in the east, Somali regional state in south east, SNNPR in the north and west and one international boundary with Kenya. The capital city of the zone is Yabello which is located at distance of $570 \mathrm{~km}$ from Addis Ababa. Borena zone has an area of about $63,939 \mathrm{~km}^{2}$. A large area of the zone is found at altitude below 1500 above sea levels with semi-arid climate.

The climate of the zone varies from hot tropical to warm temperate. About $56 \%$ of the total climatic condition of the zone characterized by tropical/ kola climatic condition while about $31 \%$ and $13 \%$ of the total area of the zone characterized by sub-tropical/ Woina Dega and Dega agro climatic conditions respectively. The major soils in the Borena zone are chromic, orthic, luvisols, ortnic, acrisols, calcoric and eutric fluvisols and chromic eutric and calcic combisols. Broad leafed forests, wood land, bush and shrub land, grass land and plantations trees are found in the zone (Figure 1).

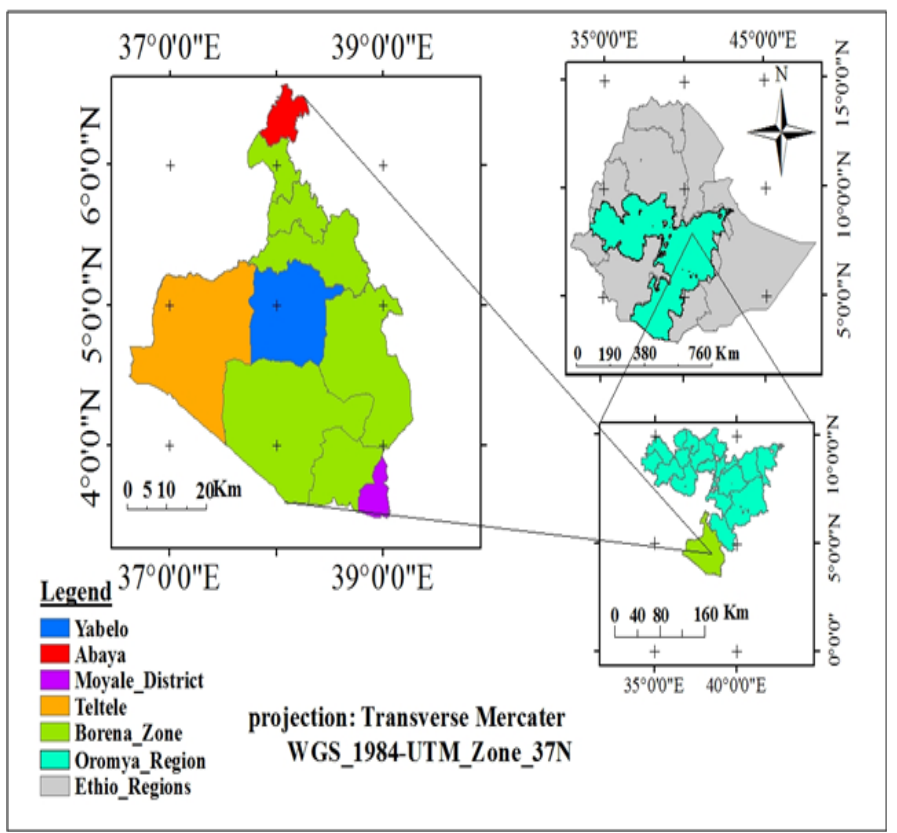

Figure I Administrative Map of the Study Area.

\section{Method of data collection}

The study zone and districts were selected purposively on the basis of the level of Xanthium strumarium invasion with the help of information obtained from Agricultural office of Borena Zone .Based on the above selection criteria, four districts were selected. The impact of Invasive Alien Plant Species, Xanthium strumarium, on the species richness, evenness, diversity and composition of invaded communities was studied by applying quadrats Method following Dogra et al. ${ }^{13}$ and Gebrehiwot and Berhanu. ${ }^{14}$ To examine the effects of Xanthium strumarium invasions on the species richness, evenness, diversity and composition of invaded communities, a total of 96 , one meter square area, quadrats were sampled (48quadrats for invaded and 48 quadrats for non-invaded or control). In each study site (in four districts), 24, one meter square (12quadrats for invaded and 12 quadrats for non-invaded or control) quadrats was sampled. A control was selected so as to compare the species richness, evenness, diversity and composition of vegetation in the invaded and non invaded areas. In each quadrat, one quadrat of the pair was placed in heavily invaded vegetation ("invaded quadrats") where the invader was dominant and had a high cover, and the second quadrat was placed in neighboring vegetation where Xanthium strumarium had no cover ("non-invaded 
quadrats"/control).As much as possible, the un-invaded quadrats was chosen to have as similar site conditions $(<10 \mathrm{~m})$ to the invaded quadrats. The location of each quadrat and study sites were recorded with the help of a GPS.

\section{Method of data analysis}

The collected data was analyzed using SPSS (statistical package for social sciences). A descriptive statistical method was employed to analyze and summarize the data and to calculate percentages, frequency and mean. Inferential statistical method was also employed. Linear Regression Analysis (using SPSS) was used to predict the value of a variable based on the value of another variable. The percentage of Xanthium strumarium per quadrat was taken as the independent variables while species richness, diversity and evenness were taken as the dependent variable or outcome variable.

Plant species diversity analysis (Shannon 1949), H') and richness and evenness $\left(\mathrm{E}=\mathrm{H}^{\prime} / \mathrm{H}^{\prime} \max \right)$ of each study sites were analyzed. Evenness was calculated as $H^{\prime} / \ln S$, where $S$ is the species richness expressed as the number of species. ${ }^{15,16}$ Differences in species richness $S$, Simpson 1-D index of dominance, Shannon index of diversity $\mathrm{H}^{\prime}$ and evenness between invaded and non-invaded plots/controls are used to measure the effect of invasion on these community characteristics. Simpson index of dominance is calculated using the formula, $\mathrm{D}=\mathrm{N}$ $(\mathrm{N}-1) / \Sigma \mathrm{ni}(\mathrm{ni}-1)$ Where $\mathrm{n} i$ is the number of individuals in the $\mathrm{i}^{\text {th }}$ plant species; $\mathrm{N}$ is the total number of individuals plant species. The species richness $\mathrm{R}$, was taken as a measure of diversity at the plot scale. In addition, for invasive species studied, the total numbers of plant species recorded in all plots with invaded and non-invaded vegetation was used as a measure of the impact of invasion on diversity of the plants. Species richness is measured by Index of richness (denoted by R) given by Margalef (1958).

To assess the impact of invasion on species composition and relative covers of resident species, the Jaccard's similarity coefficient and Beta diversity index for invaded and un-invaded/control study sites, was calculated based on species covers. ${ }^{15} \mathrm{It}$ is calculated using the formula $\beta=1-C \mathrm{j}$, where $\mathrm{Cj}$ is Jaccard's similarity index, $\mathrm{Cj}=\mathrm{j}$ / $(\mathrm{a}+\mathrm{b}-\mathrm{j})$,Where $j=$ the number of plant species shared by invaded plant communities a and non-invaded $\mathrm{b}, a=$ the number of plant species in invaded community a, and $b=$ the number of plant species in non-invaded $b .{ }^{17}$ All the plant species appeared in the invaded and non invaded/control areas were sampled and identified. The majority of species collected from the quadrates were identified in the field. For species difficult to identify in the field, voucher specimen was collected, pressed and dried properly and transported to Ethiopian Biodiversity Institute for further identification and proper naming. The nomenclature of the plant species followed the flora of Ethiopia and Eritrea.

\section{Results and discussions}

\section{Impact of Xanthium strumarium coverage on species diversity, evenness and richness}

The results of this study indicated the invasion of Xanthium strumarium severely affected the diversity and composition of vegetation in the study area. Hence, there were 70 species found in the control or non-invaded area. On the other hand, there were 31 species found in Xanthium strumarium invaded area. The number of species reduced by $55.71 \%$ in the Xanthium strumarium invaded area as compared to non-invaded area. In addition, Simpson_1-D index of dominance, Shannon H index diversity, Margalef's index of species richness, and evenness index were reduced by $70.33 \%, 75.26 \%$, $59.368 \%$ and $69.39 \%$, respectively in the Xanthium strumarium invaded areas (Table 1). A recent similar study by Berhanu Lemma et al., ${ }^{11}$ indicated that Xanthium strumarium is one of the most severe Invasive Alien plant species which dominated on rangelands of Borana and Guji Zones of Oromia Regional State, Ethiopia. In addition, Rezene Fessehaie \& Taye Tessema ${ }^{10}$ on Alien Plant Species Invasions in Ethiopia: Challenges and Responses, indicated that Xanthium strumarium is one of the top 20 invasive alien plant species those posing negative impacts on Ethiopian biodiversity (Figure 2).

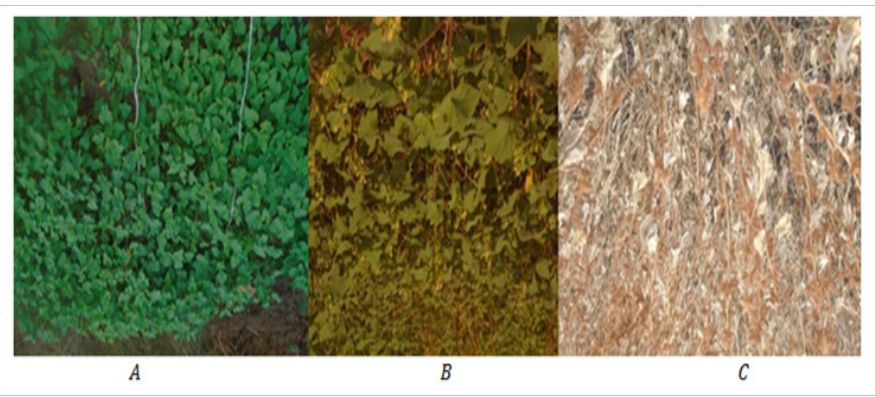

Figure 2 Xanthium strumarium (habit prior to flowering) (A), habit of mature plant (B) and dried plants (C), (Photo by Nigusse Seboka and Amare Seifu).

Table I Impact of Xanthium strumarium invasion on the plant diversity, Richness, and Evenness (Es) in the study.

\begin{tabular}{lllll}
\hline No. & Parameters & $\begin{array}{l}\text { Control/ } \\
\text { non- } \\
\text { invaded }\end{array}$ & Invaded & $\begin{array}{l}\% \\
\text { Decrease } \\
\text { over } \\
\text { control }\end{array}$ \\
\hline I & Richness(Total Species) & 70 & 31 & $55.71 \%$ \\
2 & $\begin{array}{l}\text { Simpson's Index of } \\
\text { Dominance (I-D) }\end{array}$ & 0.9229 & 0.2738 & $70.33 \%$ \\
\hline 3 & $\begin{array}{l}\text { Shannon's Index of } \\
\text { Diversity (H') }\end{array}$ & 3.234 & 0.8 & $75.26 \%$ \\
\hline 5 & $\begin{array}{l}\text { Margalef Index of } \\
\text { Richness(R) }\end{array}$ & 8.673 & 3.524 & $59.37 \%$ \\
\hline & $\begin{array}{l}\text { Index of Evenness (Es) } \\
\text { Jaccard's similarity } \\
\text { index between Control } \\
\text { and Invaded community }\end{array}$ & 0.7613 & 0.233 & $69.39 \%$ \\
\hline & $\begin{array}{l}\text { Beta diversity index } \\
\text { between Control and } \\
\text { Invaded community }\end{array}$ & 0.616 & & \\
\hline
\end{tabular}

The mean evenness value of the entire invaded sampled study sites was 0.27 indicated that $27 \%$ of the plant communities had uniform distribution while the mean evenness value of the controls (un-invaded) samples was 0.74 indicated that $74 \%$ of the plant communities had uniform distribution. Thus, the heterogeneity of the invaded study sites was reduced by $47 \%$. Evenness (E) has values between 0 and 1.0 , where 1.0 represents a situation in which all species are equally abundant. ${ }^{18}$ On the other hand, a low value of the Simpson diversity index suggests an area is dominated by a few species, homogenous (in invaded sites). If there are more successful species with no species completely dominating the area, the value of the Simpson diversity 
index is high (the control/non-invaded sites) so that the communities were more heterogeneous in the non-invaded study areas (Table 1). The Jaccard's similarity index of the communities in the invaded and non-invaded areas was only $38.4 \%$, which shows clear indication of loss of species due to invasion of Xanthium strumarium and that of the dissimilarity index (Beta diversity index) was 61.6\% (Table 1). Other similar study by Grice ${ }^{19}$ on the impacts of invasive plant species on the biodiversity of Australian rangelands indicated that Xanthium strumarium grows faster having short life cycle, greater reproductive potential, competitive ability and allelopathy that make it successful invader.

Concerning to the impact of Xanthium strumarium coverage on Species diversity, evenness and richness in each district was summarized in Table 2. From the four districts, Teltele was severely affected by the invasion of Xanthium strumarium. In this district, the number of species decreased by $79.17 \%$ in the Xanthium strumarium invaded area as compared to control. Further, Simpson_1-D index of dominance, Shannon_H index diversity, Margalef's index of species richness, and evenness index were reduced by $94.25 \%$, $94.28 \%, 82.7 \%$ and $88.71 \%$, respectively in the Xanthium strumarium invaded areas of Teltele district. A low value for the index diversity in invaded area at Teltele district indicates that the invaded area of the district is dominated by a limited number of species. It could be the

Table 2 Impact of Xanthium strumarium invasion on plant diversity, Richness, and Evenness (E) in each of the study district

\begin{tabular}{|c|c|c|c|c|c|}
\hline No. & Name of study site & Parameters & Control/non-invaded & Invaded & $\%$ Decrease over control \\
\hline \multirow[t]{5}{*}{ I } & Moyale & C & 25 & 11 & $56 \%$ \\
\hline & & I-D & 0.8447 & 0.3303 & $60.90 \%$ \\
\hline & & 'H’ & 2.431 & 0.7839 & $67.75 \%$ \\
\hline & & $\mathrm{R}$ & 3.857 & 1.372 & $64.43 \%$ \\
\hline & & $\mathrm{E}$ & 0.7554 & 0.329 & $56.45 \%$ \\
\hline \multirow[t]{5}{*}{2} & Yabello & C & 28 & 8 & $71.43 \%$ \\
\hline & & I-D & 0.9162 & 0.3264 & $64.37 \%$ \\
\hline & & 'H’ & 2.818 & 0.6998 & $75.17 \%$ \\
\hline & & $\mathrm{R}$ & 4.258 & 0.9533 & $77.60 \%$ \\
\hline & & $\mathrm{E}$ & 0.8458 & 0.3365 & $50.93 \%$ \\
\hline \multirow[t]{5}{*}{3} & Teltele & C & 24 & 5 & $79.17 \%$ \\
\hline & & I-D & 0.8662 & 0.04978 & $94.25 \%$ \\
\hline & & 'H’ & 2.384 & 0.1363 & $94.28 \%$ \\
\hline & & $\mathrm{R}$ & 3.786 & 0.655 & $82.70 \%$ \\
\hline & & $\mathrm{E}$ & 0.7501 & 0.0847 & $88.71 \%$ \\
\hline \multirow[t]{5}{*}{4} & Abaya & C & 28 & 13 & $53.57 \%$ \\
\hline & & I-D & 0.7794 & 0.3344 & $57.10 \%$ \\
\hline & & 'H' & 2.047 & 0.864 & $57.79 \%$ \\
\hline & & $\mathrm{R}$ & 3.807 & 1.799 & $52.74 \%$ \\
\hline & & $\mathrm{E}$ & 0.6144 & 0.3369 & $45.17 \%$ \\
\hline
\end{tabular}

Caution Richness(C); Simpson's Index of Dominance (I-D); Shannon's Index of Diversity (H'); Margalef Index of Richness(R); Index of Evenness (E) result of the high invasion of Xanthium strumarium with only a few species being really well adapted to that environment. If those few species that can survive are seriously affected, then the ecosystem that contains the species may be disturbed as compared to control. Change in the environment would probably have quite serious effects. Similar study conducted on Monitoring plant diversity by George ${ }^{20}$ reported low value of the index diversity suggested an area is dominated by a limited number of plant species.

In contrast, Abaya district was the least affected by the invasion of Xanthium strumarium. In this district, the number of species decreased by $53.57 \%$ in the Xanthium strumarium invaded area as compared to control. Further, Simpson_1-D index of dominance, Shannon_H index diversity, Margalef's index of species richness, and evenness index were reduced by $57.1 \%, 57.79 \%, 52.74 \%$ and $45.17 \%$ respectively in the Xanthium strumarium invaded areas. A high diversity index in invaded area of Abaya district as compared to invaded area of Teltele district suggests that the invaded area in Abaya district was not dominated by one or two species (Table 2). This could be due to the extent of invasion of Xanthium strumarium in Abaya district lower than the other study districts as well. This intern may be resulted from the variation in altitude, soil type, temperature and climate. 


\section{Relationship between coverage (percentage) of Xan- thium strumarium and species diversity, evenness and richness in the study areas}

The regression analysis showed a strong negative relationship between the coverage (percentage) of Xanthium strumarium and species richness per study site and per quadrat .Hence, the regression equation can be presented as: $\mathrm{Y}=-17.70 \mathrm{X}+23.17$, where $\mathrm{Y}$ is species richness and $\mathrm{X}$ is Percentage of Xanthium strumarium per study site. In this case, $\mathrm{R}^{2}=0.818$, or $81.8 \%$ indicated that there is a strong negative relationship between the percentage of Xanthium strumarium and species richness. As percentage of Xanthium strumarium increase species richness decease. The regression equation and Pearson correlation (-0.905) indicated the existence of strong negative linear relationship between Percentage of Xanthium strumarium and Species Richness per study site (Figure 3 ).

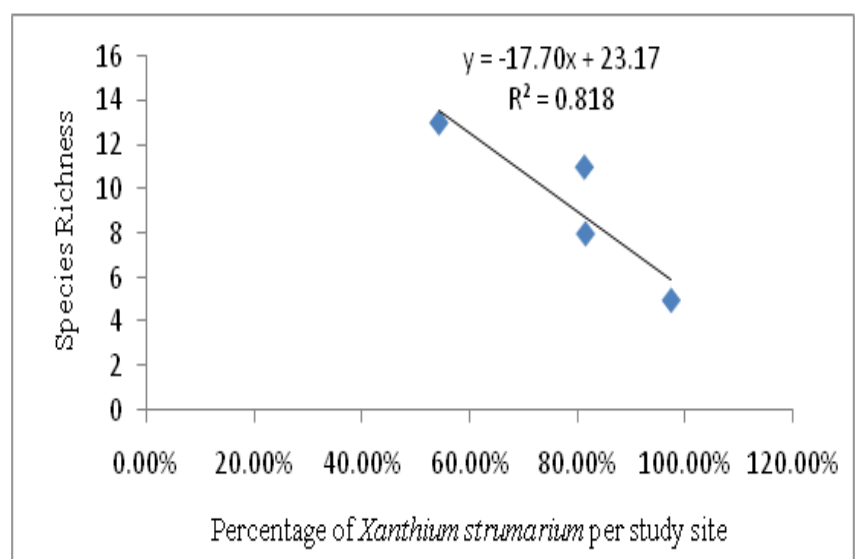

Figure 3 The relationship between Percentage of Xanthium strumarium and Species Richness per study Site $(R 2=0.818, p<0.0 I)$.

There existed strong negative linear relationship between Percentage of $X$. strumarium and Species Richness per quadrat, hence, the regression equation can be presented as: $Y=-13.47 \mathrm{X}+$ 16.74, where $\mathrm{Y}$ is Species Richness and $\mathrm{X}$ is Percentage of Xanthium strumarium per quadrat. In this case, $\mathrm{R}^{2}=0.741$, or $74.1 \%$ indicated that there is a strong negative relationship between the percentage of Xanthium strumarium and Species Richness per quadrat. The regression equation and Pearson correlation $(-0.861)$ indicated the existence of strong negative linear relationship between Percentage of Xanthium strumarium and Species Richness per quadrat in the study sites. As the percentage of Xanthium strumarium increase, Species Richness per quadrat decrease (Figure 4).

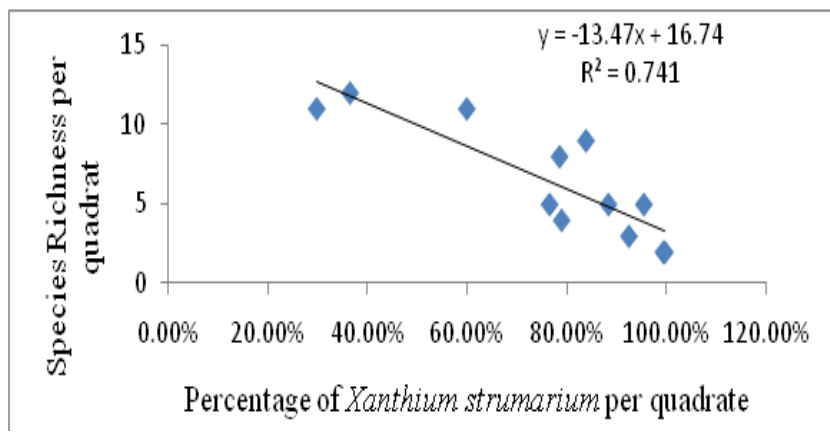

Figure 4 The relationship between Percentage of Xanthium strumarium and Species Richness per Quadrat.
The results indicated that there is also strong negative linear relationship between the percentage of Xanthium strumarium and evenness of plant species in the study sites. Hence, the regression equation can be presented as: $\mathrm{Y}=-0.496 \mathrm{X}+0.661$, where $\mathrm{Y}$ is Evenness and $\mathrm{X}$ is Percentage of Xanthium strumarium per study site. In this case, $\mathrm{R}^{2}=0.508$, or $50.8 \%$ indicated that there is a strong negative relationship between the percentage of Xanthium strumarium and evenness of plant species. The regression equation and Pearson correlation (-0.713) indicated the existence of strong negative linear relationship between Percentage of Xanthium strumarium and evenness of plant species in the study sites (Figure 5). As the data in Figure 6 portrays, Shannon_H index diversity generally decrease with the corresponding increase in the Percentage of Xanthium strumarium. The regression analysis also showed a strong negative relationship between the coverage of Xanthium strumarium Shannon_H index diversity $\left(\mathrm{r}^{2}=0.656\right.$ or $\left.65.6 \%\right)$ (Figure 6$)$. The negative relationship between Percentage (coverage) of Xanthium strumarium and Species diversity, evenness and richness in the study areas might be due to Xanthium strumarium has allopathic property and high productive mechanism than indigenous plants in the area. In other words it might be due to the environmental conditions (soil, temperature, rainfall, altitude etc.) were favorable to Xanthium strumarium than the other plants in the study areas. Moreover, other similar study by Kaur et al. ${ }^{21}$ and Löve \& Dansereau ${ }^{22}$ confirmed that Xanthium strumarium can tolerate a variety of soil conditions ranging from moist clay to dry sand. It also tolerates flooding at all growth stages. Their study also indicated, Xanthium strumarium is able to grow in different types of habitat such as cultivated fields, vacant lots, sandpits, and dry washes; on beaches and sand dunes; and along the shores of ponds and rivers, especially riverbeds left barren by receding floodwater. Therefore, such ecologically diversified adaptability of Xanthium strumarium allows its rapid expansion and speedup the damaging impacts on animals and plants as well as their products, resulting in monoculture formation and native biodiversity reduction.

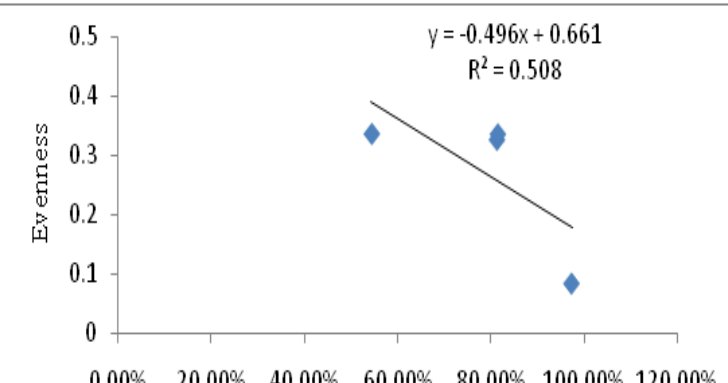

Percentage of Xanthium strumariwm per study site

Figure $\mathbf{5}$ The relationship between Percentage (coverage) of Xanthium strumarium and Evenness of Plants per study site.

\section{Impact of Xanthium strumarium invasion on the flo- ristic composition of the plants communities}

Xanthium strumarium invasion heavily distresses the composition and structure of plant species in the invaded study areas. A total of 73 plant species belonging to 25 families of plants were collected during the current study (both in invaded and non-invaded areas). The number of plant families was 24 in the control area in contrast to only 15 in the Xanthium strumarium invaded areas. The number of family decreased by $37.5 \%$ in the Xanthium strumarium invaded area as compared to control. In invaded areas, of the 15 plant families, Asteraceae accounts the highest $22.6 \%$, followed by Poaceae $12.9 \%$, 
Amaranthaceae, Fabaceae and Lamiaceae accounts 9.7\% each share the third place among the plant species recorded in the Xanthium strumarium invaded study areas (Table 3 ). These five families afforded $64.6 \%$ of species to the total flora in Xanthium strumarium invaded study areas. In non-invaded areas, of the 24 plant families, Poaceae accounts the highest $17.8 \%$, followed by Asteraceae $15.1 \%$, Fabaceae and Amaranthaceae, accounts $12.3 \%$ and $11.0 \%$ holding the third and fourth place respectively among the plant species recorded in the non-invaded (controlled) study areas (Table 4). These four families contributed $56.2 \%$ of species to the total flora in non-invaded (controlled) study areas. Among 73 plant species, 28 species were found common in control and invaded areas. Xanthium strumarium was found to be the most dominant plant species in invaded study sites followed by Parthenium hysterophorus and Cynodon dactyon respectively (Table 5). Similar study in some districts of Amhara and Southern regions of Ethiopia also indicated relatively high abundance of Xanthium strumarium compared to Parthenium hysterophorus, and Cynodon aethiopicus. ${ }^{23}$

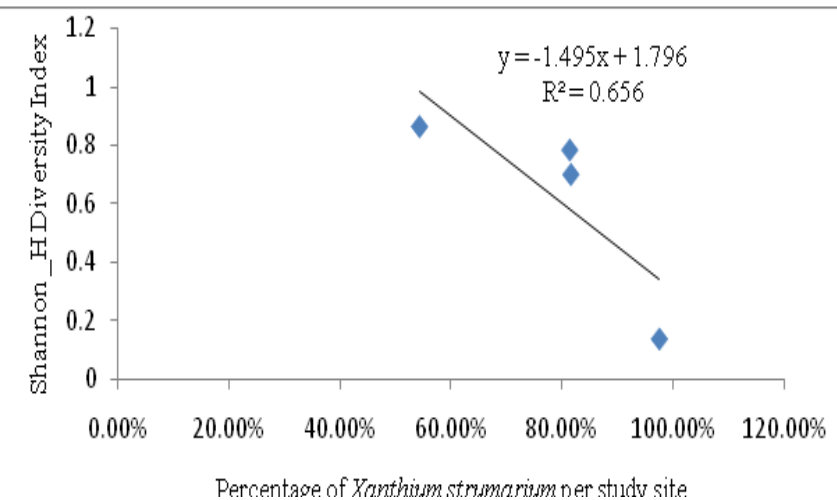

Figure 6 the Relationship between Shannon Diversity Index and Percentage of Xanthium strumarium.

Table 3 Number and percentage of plant species within the total families' in four study sites (Xanthium strumarium Invaded areas).

\begin{tabular}{lllll}
\hline No. & Family & $\begin{array}{l}\text { Number } \\
\text { of species }\end{array}$ & $\begin{array}{l}\text { Percent } \\
\text { flora }\end{array}$ & $\begin{array}{l}\text { Cumulative } \\
\text { percent }\end{array}$ \\
\hline I & Acanthaceae & I & 3.2 & 3.2 \\
2 & Alliaceae & 1 & 3.2 & 6.5 \\
3 & Amaranthaceae & 3 & 9.7 & 16.1 \\
4 & Apiaceae & I & 3.2 & 19.4 \\
5 & Asteraceae & 7 & 22.6 & 41.9 \\
6 & Boraginaceae & 1 & 3.2 & 45.2 \\
7 & Brassicaceae & 1 & 3.2 & 48.4 \\
8 & Cucurbitaceae & 1 & 3.2 & 51.6 \\
9 & Fabaceae & 3 & 9.7 & 61.3 \\
10 & Lamiaceae & 3 & 9.7 & 71 \\
II & Papaveraceae & 1 & 3.2 & 74.2 \\
12 & Poaceae & 4 & 12.9 & 87.1 \\
13 & Polygonaceae & 2 & 6.5 & 93.5 \\
14 & Ranunculaceae & 1 & 3.2 & 96.8 \\
15 & Verbenaceae & I & 3.2 & 100 \\
& Total & 31 & 100 & \\
\hline
\end{tabular}

Table 4 Number and percentage of plant species within the total families' in four study sites.

(In the control/non- invaded areas).

\begin{tabular}{|c|c|c|c|c|}
\hline No. & Family & $\begin{array}{l}\text { Number of } \\
\text { species }\end{array}$ & $\begin{array}{l}\text { Percent } \\
\text { flora }\end{array}$ & $\begin{array}{l}\text { Cumulative } \\
\text { percent }\end{array}$ \\
\hline I & Acanthaceae & I & 1.4 & 1.4 \\
\hline 2 & Alliaceae & 2 & 2.7 & 4.1 \\
\hline 3 & Amaranthaceae & 8 & 11 & 15.1 \\
\hline 4 & Apiaceae & 2 & 2.7 & 17.8 \\
\hline 5 & Araceae & 2 & 2.7 & 20.5 \\
\hline 6 & Asphodelaceae & I & 1.4 & 21.9 \\
\hline 7 & Asteraceae & 11 & 15.1 & 37 \\
\hline 8 & Brassicaceae & I & 1.4 & 38.4 \\
\hline 9 & Capparidaceae & I & 1.4 & 39.7 \\
\hline 10 & Chenopodiaaceae & I & 1.4 & 41.1 \\
\hline 11 & Commelinaceae & I & 1.4 & 42.5 \\
\hline 12 & Cucurbitaceae & I & 1.4 & 43.8 \\
\hline 13 & Cyperaceae & I & 1.4 & 45.2 \\
\hline 14 & Euphorbiaceae & I & 1.4 & 46.6 \\
\hline 15 & Fabaceae & 9 & 12.3 & 58.9 \\
\hline 16 & Lamiaceae & 5 & 6.8 & 65.8 \\
\hline 17 & Malvaceae & I & 1.4 & 67.1 \\
\hline 18 & Menispermaceae & I & 1.4 & 68.5 \\
\hline 19 & Papaveraceae & I & 1.4 & 69.9 \\
\hline 20 & Poaceae & 13 & 17.8 & 87.7 \\
\hline 21 & Polygonaceae & 4 & 5.5 & 93.2 \\
\hline 22 & Ranunculaceae & I & 1.4 & 94.5 \\
\hline 23 & Solanaceae & 2 & 2.7 & 97.3 \\
\hline \multirow[t]{2}{*}{24} & Verbenaceae & 2 & 2.7 & 100 \\
\hline & Total & 73 & 100 & \\
\hline
\end{tabular}

Table 5 Floristic composition of the plant communities in the non-invaded and invaded areas.

Total species=73; Total species in control site=70; Total species in invaded site $=31$; Common species $=28$.

\begin{tabular}{llll}
\hline No. & Name of plants & $\begin{array}{l}\text { Control/ } \\
\text { non-invaded }\end{array}$ & Invaded \\
\hline I & Acacia drepanolobium & $\checkmark$ & X \\
2 & Aerva sp. & $\checkmark$ & X \\
3 & Aloe yavellana & $\checkmark$ & $X$ \\
4 & Alternanthera nodiflora & $\checkmark$ & $X$ \\
5 & Amaranthus cruentus & $\checkmark$ & $X$ \\
6 & Amaranthus graecizans & $\checkmark$ & $X$ \\
7 & Amaranthus palmeri & $\checkmark$ & $X$ \\
8 & Amaranthus spinosus & $\checkmark$ & $\checkmark$ \\
9 & Argemone ochroleuca & $\checkmark$ & $X$ \\
10 & Bidens macroptera & $\checkmark$ & $X$ \\
\hline
\end{tabular}




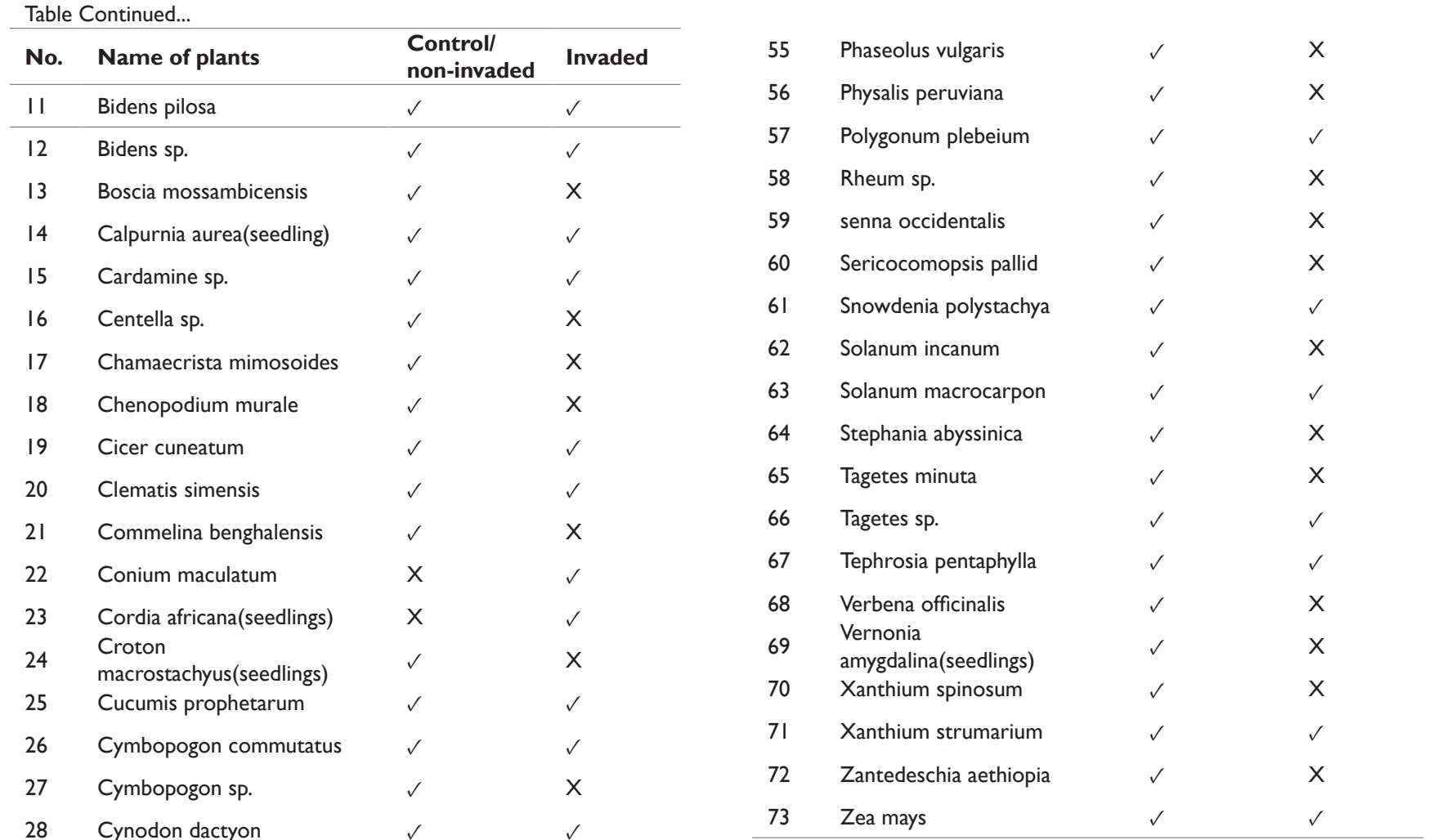

$\begin{array}{llll}29 & \text { Cyperus rotundus } & \checkmark & \checkmark \\ 30 & \text { Datura stramonium } & \checkmark & \times\end{array}$

\section{Conclusion and recommendation}

Xanthium strumarium categorized as the dominant invasive alien species in Borena zone, Oromia Regional State, Ethiopia that reduced species richness, diversity, composition and evenness of various plant species in invaded communities. Therefore, there is a need of better planning to control, manage and eradicate the spread of Xanthium strumarium by establishing communication links between Regional, Zonal, district and Kebele Agricultural Office and other concerned bodies. In addition to this, strong local support and commitment from the government and individuals will more likely facilitate in the control, management and/or eradication of Xanthium strumarium on private land before it spreads to other districts, zones and regions.

\section{Acknowledgments}

The people of Borena Zone, Oromia Region who gave us information are gratefully acknowledged. We are grateful to Ethiopian Biodiversity Institute (EBI) for financial support during field work. We are also grateful to Agricultural workers of Borena Zone who helped us in different ways. Finally, we are indebted very much to Moyale, Yabelo, Teltele and Abaya districts farmers for their unreserved willingness to share their time and knowledge with us.

\section{Conflict of interest}

Authors declare there is no conflict of interest.

\section{References}

1. Genovesi and Shine C. European strategy on IAS Convention on the Conservation of European Wildlife and Habitats (Bern Convention). Nature and environment, No. 137 Council of Europe, Switzerland; 2004. p. $1-68$.

2. Space JC and Imada CT. Report to the Republic of Kiribati on Invasive Plant Species on the Islands of Tarawa, Abemama, Butaritari and Maiana. Contribution No. 2003-006 to the Pacific Biological Survey, Honolulu, Hawai'i, USA; 2004. p. 1-105. 
3. Taye Tessema, Ulrichs C, Buettner C. Invasive Alien plant Species in Ethiopia: impacts, challenges and responses. 2003.

4. Lisanework Nigatu, Asresie Hassen, Sharma J, et al. Impact of Parthenium hysterophorus on grazing land communities in north-eastern Ethiopia. Journal compilation. 2010;10(3):143-152.

5. Dekker J. Weed species seed heteroblasty examples. Evolutionary ecology of weeds, Iowa 50010. USA; 2011. p. 160-179.

6. Stesevic D, Petrovic D. Preliminary list of plant invaders in Montenegro. Biologica Nyssana. 2010;1(1-2):35-42.

7. Weaver SE, Lechowicz MJ. The biology of Canadian weeds. Xanthium strumarium L. Can J plant sci. 1982;63(1):211-225.

8. Hussain Z, Marwat KB, Cardina J, et al. Xanthium strumarium L. impact on corn yield and yield components. Turk J Agri For. 2014;38(1):39-46.

9. Sartorato I, Berti A, Zanin G. Estimation of economic thresholds for weed control in soybean (Glycine max (L.) Merr.). Crop Protection. 1996;15:63-68.

10. Rezene Fessehaie, Taye Tessema. Alien Plant Species Invasions in Ethiopia: Challenges and responses join the fight against invasive species. 2010

11. Berhanu Lemma, Taye Tessema, Rezene Fessehaie. Distribution, abundance and socio-economic impacts of invasive plant species (IPS) in Borana and Guji Zones of Oromia National Regional State, Ethiopia. Basic Res J Agri Sci. 2015;4(9):271-279.

12. Mulugeta KW. Biological assessment and farmers' perception on socioeconomic impact of Parthenium hysterophorus on native biodiversity in Kobo. MSc thesis: AAU, Amhara Region, Ethiopia. 2006.

13. Dogra KS, Kohli RK, Sood SK, et al. Impact of Ageratum conyzoides L. on the diversity and composition of vegetation in the Shivalik hills of Himachal Pradesh (Northwestern Himalaya), India. International Journal of Biodiversity and Conservation. 2009;1(5):135-145.
14. Gebrehiwot N, Berhanu L. Impact of Parthenium on species diversity in Gamo Gofa, Ethiopia. Scholarly Journal of Agricultural Science. 2015;5(7):226-231

15. Hejda M, Pysek P, Jarosík V. Impact of invasive plants on the species richness, diversity and composition of invaded communities British Ecological Society. Journal of Ecology. 2009;97(3):393-403.

16. Hill MO. Diversity and its evenness, a unifying notation and its consequences. J of Ecology. 1973;54(2):427-432.

17. Baselga A. Partitioning the turnover and Nested components of beta diversity. Global Ecology and Biogeography. 2010;19(1):134-43.

18. Nagendra H. Opposite trends in response for the Shannon and Simpson Indices of Landscape diversity. Applied Geography. 2002;22:175-186.

19. Grice AC. The impacts of invasive plant species on the biodiversity of Australian rangelands. Rangeland Journal. 2006;28:27-35.

20. George BC. Monitoring plant diversity: Simpson's index and species Richness Assessment. Canadian Forest Products Ltd, Timberline Forest Inventory Consultants Ltd, Canada; 2003. p. 1-25.

21. Kaur B, Bhatia S, Sharma KK. Diversity and impact of invasive alien plant species of family Asteraceae in Jammu district (Jammu and Kashmir, India). International Journal of Interdisciplinary and Multidisciplinary Studies. 2014;1(8):51-62.

22. Löve D, Dansereau P. Biosystematic studies on Xanthium: taxonomic appraisal and ecological status. Canadian Journal of Botany. 1959;37(2):173-208.

23. Belayneh Bufebo, Taye Tessema, Rezene Fisshaie. Spatial Distribution and Abundance of Invasive Alien Plant Species in Gamo Gofa Zone, Ethiopia. International Journal of Innovative Research \& Development. 2016;5(1):23-33. 